\title{
Coschappen in het buitenland niet geschikt voor alle coassistenten*
}

\author{
A. Bast
}

Geneeskunde studeren is hard werken en van een medicus wordt veel verwacht. Het is moeilijk om het vereiste niveau te bereiken in zes jaar. Als docent en als voorzitter van de examencommissie aan de Universiteit Maastricht valt me dat telkens weer op. Daarom is er geen ruimte voor een buitenlands coschap, zoals ik met enkele voorbeelden zal laten zien.

Voorbeeld 1: Een geneeskundestudente wordt vanwege uiterst magere studievoortgang door de examencommissie opgeroepen om haar resultaten te bespreken. De studente merkt tijdens het gesprek op dat zij graag een extra coschap wil volgen omdat zij denkt dat zij van het coschap in het buitenland te weinig heeft geleerd van de westerse methodieken. Helaas kan dat niet. Een eenmaal behaald coschap is immers afgetekend. Als de studente de kamer verlaten heeft, overleg ik met de secretaris: waarom mag een matig presterende student stage in het buitenland volgen? Die heeft de handen al meer dan vol om de studie goed te volbrengen.

Voorbeeld 2: Aan het eind van een coschap interne geneeskunde staat een evaluatieweek gepland. De student draagt tijdens deze week een praktijkervaring aan om farmacotherapeutische aspecten te bespreken. Als docent Farmacotherapie merk ik op dat twee studenten dezelfde casus pre- senteren. Bij navraag blijkt dat zij tijdens hun coschap interne geneeskunde in ZuidAfrika te weinig ervaringen hebben opgedaan met medicamenteuze therapie om ieder een eigen casus te kunnen aandragen. Als docent vraag ik mij af wat zij dan wel opgestoken hebben tijdens dit coschap.

Voorbeeld 3: Een geneeskundestudente meldt zich bij de examencommissie omdat zij niet kan deelnemen aan het voortgangstentamen, de longitudinale toets middels vier deeltoetsen per jaar om de kennisontwikkeling te toetsen. De studente heeft drie studieonderdelen in het buitenland gepland, waardoor zij te weinig aanwezig is om alle vier de toetsen af te leggen. Wat nu? Moet zij studievertraging accepteren of moet de examencommissie het afleggen van de toets niet als verplicht beschouwen?

Deze voorbeelden illustreren dat men bij het volgen van coschappen in het buitenland niet voldoende leert. Westerse methoden, technieken en therapieën waar de arts kennis van moet hebben, komen vaak niet aan bod. Voorts is het bij verblijf in het buitenland niet meer mogelijk om longitudinaal kennisvermeerdering te toetsen.

Stel coschappen in het buitenland beschikbaar voor de student die het aankan. Houd ze beschikbaar voor de student die specifiek kiest voor een internationaal traject, bijvoorbeeld om tropenarts te worden.

\footnotetext{
* Dit artikel is ook verschenen in het Nederlands Tijdschrift voor Geneeskunde (Ned Tijdschr Geneeskd. 2009;153:B306)
} 
Bouw daar een curriculum omheen om de student optimaal voor te bereiden op zo'n stage.

Studeren is kwaliteit bereiken, zich scholen op diverse fronten en uiteenlopende competenties verwerven zoals medisch handelen, communicatie, samenwerking, kennis, wetenschap, maatschappelijk handelen, regie/coördinatie en professionaliteit. Dat is voor velen al moeilijk genoeg in Nederland en een stage in het buitenland draagt hier niet aan bij. De universiteit is geen reisbureau.
De auteur:

Prof. dr. A. Bast is toxicoloog, Universiteit Maastricht, Vakgroep Farmacologie en Toxicologie, Maastricht.

Correspondentiedres:

a.bast@farmaco.unimaas.nl

Belangenconflict: geen gemeld

Financiële ondersteuning: geen gemeld 